\title{
ANALISIS FAKTOR-FAKTOR YANG BERHUBUNGAN DENGAN KEPATUHAN PASIEN PENDERITA GAGAL GINJAL KRONIK DALAM MENJALANI TERAPI HEMODIALISA DI RUANGAN HEMODIALISA RSUP HAJI ADAM MALIK MEDAN TAHUN 2014
}

\author{
Afniwati, Amira Permata Sari Tarigan, Yunita Ayu Lestari Tarigan \\ Jurusan Keperawatan Poltekkes Kemenkes Medan
}

\begin{abstract}
Abstrak
Prevalensi gagal ginjal kronik (GGK) meningkat dari tahun ke tahun. Jumlah gagal ginjal tahun 2009 di Amerika Serikat rata-rata prevalensinya $10-13 \%$ atau sekitar 25 juta orang yang terkena penyakit ginjal kronik. Sedangkan di Indonesia tahun 2009 prevalensiya $12,5 \%$ atau 18 juta orang dewasa yang terkena penyakit gagal ginjal kronik. Hemodialisa adalah suatu terapi pada klien GGK dengan menggunakan mesin dialiser yang berfungsi sebagai ginjal buatan. Banyak faktor yang mempengaruhi kepatuhan pasien gagal ginjal kronik dalam menjalani terapi hemodialisa. Faktor tersebut antara lain pengetahuan, sumber biaya, pendidikan, dan umur. Penelitian ini bertujuan untuk mengalisis faktor-faktor yang berhubungan dengan kepatuhan pasien penderita gagal ginjal kronik dalam menjalani terapi hemodialisa di ruangan hemodialisa RSUP Haji Adam Malik Medan Tahun 2014. Penelitian ini bersifat analitik. Populasi dalam penelitian ini berjumlah 120 responden dan sampel dalam penelitian ini berjumlah 30 responden dengan menggunakan teknik sistematik random sampling. Dari hasil penelitian yang dilakukan menunjukkan bahwa responden yang memiliki pengetahuan baik sebanyak 46,7\%, yang memakai sumber biaya BPJS 83,3\%, yang memiliki pendidikan SMA sebanyak 46,7\%, dan yang berumur > 40 tahun sebanyak 73,3\%. Dari hasil tersebut dapat diketahui bahwa ada hubungan yang bermakna antara sumber biaya dengan kepatuhan pasien penderita gagal ginjal kronik dalam menjalani terapi hemodialisa setelah dilakukan uji chi-square dengan nilai $\mathrm{p}<0,05$ yaitu $\mathrm{p}=0,000$. Begitu juga dengan pengetahuan, pendidikan, dan umur memiliki nilai $\mathrm{p}<0,05$ yaitu $\mathrm{p}=$ 0,001 dengan tingkat kepercayaan $95 \%$.
\end{abstract}

Kata kunci: Kepatuhan, Gagal ginjal kronik, Hemodialisa

\section{PENDAHULUAN}

Gagal ginjal kronik merupakan penyakit ginjal yang sudah tidak mampu mempertahankan lingkungan internal yang konsisten dengan kehidupan dan pemulihan fungsi tidak dimulai. Pada kebanyakan individu transisi dari sehat ke status kronik atau penyakit yang menetap sangat lamban dan menunggu beberapa tahun ( Haryono, 2013).

Bila seseorang mengalami penyakit ginjal kronik sampai pada stadium akhir, dimana laju filtrasi glomerulus $\leq 15 \mathrm{ml} / \mathrm{menit}$, ginjal tidak mampu lagi menjalankan seluruh fungsinya dengan baik. Maka dibutuhkan terapi untuk menggantikan fungsi ginjal tersebut seperti, dialisa dan transplantasi ginjal yang merupakan tindakan yang efektif sebagai terapi untuk gagal ginjal kronik tahap terminal (Cahyaningsih, 2009).

Hemodialisa adalah dialisis dengan menggunakan mesin dialiser yang berfungsi sebagai ginjal buatan. Pada hemodialisa, darah dipompa keluar dari tubuh, masuk ke dalam mesin dialiser. Di dalam mesin dialiser, darah dibersihkan dari zat-zat racun melalui proses difusi dan fiber oleh dialisat (suatu cairan khusus untuk dialisis), lalu dialirkan kembali ke dalam tubuh. Proses Hemodialisa dilakukan 1-3 kali seminggu di rumah sakit dan setiap kalinya membutuhkan waktu sekitar 2-4 jam (Mahdiana, 2011).

Menurut Thata, dkk (2009), angka kejadian gagal ginjal kronik meningkat dari tahun ke tahun. Jumlah gagal ginjal tahun 2009 di Amerika Serikat rata-rata prevalensinya $10-13 \%$ atau sekitar 25 juta orang yang terkena penyakit ginjal kronik. Sedangkan di Indonesia tahun 2009 prevalensiya $12,5 \%$ atau 18 juta orang dewasa yang terkena penyakit gagal ginjal kronik.

Kepatuhan pasien adalah sejauh mana perilaku pasien sesuai dangan ketentuan yang diberikan oleh professional kesehatan. Kepatuhan tersebut dilatar belakangi oleh perbedaan pengetahuan, sosial ekonomi, pendidikan, serta umur (Nevin, 2012).

Di Sumatera Utara tepatnya di RSUP Haji Adam Malik Medan jumlah pasien gagal ginjal kronik yang menjalani terapi hemodialisa dari 3 bulan terakhir yaitu bulan September s/d Desember 2013 sejumlah 701 
orang, dan pada bulan Januari tahun 2014 sejumlah 120 orang.

Berdasarkan data dari studi pendahuluan diatas penulis tertarik untuk meneliti faktor-faktor apakah yang mempengaruhi kepatuhan pasien yang menjalani terapi hemodialisa di ruang hemodialisa RSUP $\mathrm{H}$. Adam Malik Medan 2014.

\section{Kepatuhan}

Kepatuhan adalah sejauh mana perilaku-perilaku pasien dengan ketentuan yang diberikan oleh professional kesehatan (Niven, 2012).

\section{Faktor-faktor yang mempengaruhi kepatuhan pasien}

Menurut Schwart dan Grifin dalam buku psikologi kesehatan karangan Bart Smet (2006) mengatakan bahwa faktor-faktor yang mempengaruhi kepatuhan adalah Tingkat Pengetahuan, Status Ekonomi, Pendidikan,dan umur.Dimana status ekonomi merupakan salah satu faktor yang perlu diperhatikan dalam kepatuhan pasien. Apabila pasien memiliki tingkat kesejahteraan yang rendah kemungkinan pasien untuk patuh dalam terapi maupun pengobatan menjadi berkurang. Pendidikan pasien dapat meningkatkan kepatuhan, sepanjang bahwa pendidikan tersebut merupakan pendidikan yang aktif seperti penggunaan buku-buku dan kaset oleh pasien secara mandiri. Dari segi umur Kemungkinan lansia untuk patuh menjadi lebih kecil dibandingkan dengan umur anak-anak terlebih lagi pada umur yang lainnya.

\section{Gagal Ginjal Kronik (GGK)}

Gagal Ginjal Kronik (GGK) atau penyakit ginjal tahap akhir merupakan gangguan fungsi ginjal yang progresif dan irreversible dimana kemampuan tubuh gagal untuk mempertahankan metabolisme dan keseimbangan cairan dan elektrolit, menyebabkan uremia (retensi urea dan sampah nitrogen lain dalam darah) (Suharyanto, 2009. Beberapa penyakit yang dapat memicu timbulnya gagal ginjal kronik seperti Diabetes, tekanan darah tinggi (hipertensi), batu ginjal, infeksi dan Radang, glomerulonefritis dan penyalahgunaan obat-obatan.

Tanda dan gejala yang mungkin timbul adalah: Perubahan frekuensi kencing. Sering ingin berkemih pada malam hari, pembengkakan pada bagian pergelangan kaki,kram otot pada malam hari,lemah dan lesu, kurang berenergi, nafsu makan turun, mual, dan muntah dan sebagainya.Selain itu komplikasi dari gagal ginjal kronik yaitu penyakit jantung, hipertenei, anemia dan sebagainya.

\section{Terapi Hemodialisa (Cuci Darah)}

Hemodialisa berasal dari kata hemo (darah), dan dialisa (pemisahan atau filtrasi). Pada prinsipnya hemodialisa menempatkan darah berdampingan dengan cairan dialisat atau pencuci yang dipisahkan oleh suatu membran atau selaput semipermeabel. Membran ini dapat dilalui oleh air dan zat tertentu atau zat sampah.
Proses ini disebut dialisis yaitu proses berpindahnya air atau zat, bahan melalui membran semipermeabel (Callghan, 2007).

Tujuan hemodialisa adalah untuk mengeluarkan zat-zat nitrogen yang toksik dari dalam darah dan mengeluarkan air yang berlebihan. Terdapat tiga prinsip yang didasari kerja hemodialisis, yaitu difusi, osmosis, dan ultrafiltrasi. Menurut Chang (2009) terdapat indikasi dan kontra Indikasi dari terapi hemodialisa :Gagal ginjal akut, gagal ginjal kronik fase terminal disertai gejala uremia dan keracunan obat dan bahan kimia

Adapun Kendala Terapi Hemodialisa yaitu biaya mahal, fasilitas yang tersedia tidak cukup, fasilitas hanya dikota besar, tenaga teknis terampil belum cukup dan beban Unit Dialisa terus bertambah (Lumenta, 2009).

\section{Faktor-faktor yang mempengaruhi kepatuhan pasien gagal ginjal kronik dalam menjalani terapi hemodialisa}

Menurut Schwart dan Grifin dalam buku psikologi kesehatan karangan Bart Smet (2006) mengatakan bahwa faktor-faktor yang mempengaruhi kepatuhan adalah Tingkat Pengetahuan, Status Ekonomi, Pendidikan,dan umur.Dimana status ekonomi merupakan salah satu faktor yang perlu diperhatikan dalam kepatuhan pasien. Apabila pasien memiliki tingkat kesejahteraan yang rendah kemungkinan pasien untuk patuh dalam terapi maupun pengobatan menjadi berkurang. Pendidikan pasien dapat meningkatkan kepatuhan, sepanjang bahwa pendidikan tersebut merupakan pendidikan yang aktif seperti penggunaan buku-buku dan kaset oleh pasien secara mandiri. Dari segi umur Kemungkinan lansia untuk patuh menjadi lebih kecil dibandingkan dengan umur anak-anak terlebih lagi pada umur yang lainnya. Masalah ekonomi pada terapi hemodialisa merupakan masalah yang sangat mendasar, hal ini berhubungan erat dengan kemiskinan dimana secara umum kemampuan ekonomi suatu keluarga diukur dari pendapatan keluarga perbulan

\section{METODE PENELITIAN}

Desain penelitian yang digunakan adalah desain penelitian cross sectional, yaitu suatu metode yang merupakan rancangan penelitian dengan melakukan pengukuran atau pengamatan pada saat bersamaan (sekali waktu) dengan jenis penelitian analitik yaitu metode penelitian yang mencari hubungan antara variabel dependen dan variabel independen (Nursalam, 2010).

Penelitian ini dilaksanakan di Ruang Hemodialisa RSUP Haji Adam Malik Medan, dilakukan pada bulan Maret 2014 - Juni 2014.

Adapun yang menjadi populasi dalam sampel ini adalah semua pasien gagal ginjal kronik yang menjalani terapi hemodialisa pada bulan Januari 2014 sejumlah 120 orang di Ruangan Hemodialisa RSUP 
Haji Adam Malik Medan. Populasi ini merupakan pasien baru yang tidak berulang. Teknik sampel dalam penelitian ini adalah dengan menggunakan teknik sistematik random sampling. Dimana sampel diambil secara acak. Caranya adalah membagi anggota populasi dengan perkiraan jumlah sampel yang diinginkan. Hasilnya adalah interval sampel. Sampel diambil dengan mendaftar anggota populasi secara acak antara 1 sampai n, kemudian membagi dengan jumlah sampel yang diinginkan. Misalnya jumlah populasi 120, sampel yang diinginkan 30, maka intervalnya adalah $120: 30=4$, maka anggota populasi yang terkena sampel adalah setiap elemen yang mempunyai kelipatan 4, yakni 4, 8, 12, 16, dan seterusnya sampai mencapai 30 sampel.

Menurut Arikunto (2006) bila total populasi lebih dari 100, maka pengambilan sampel 10\%-15\% atau 20\%-25\% dari total populasi, dimana total 120 orang dan peneliti mengambil $25 \%$ dari total populasi maka sampel penelitian ini adalah 25/100 x $120=30$ orang. Adapun Kriteria insklusi sampel pada penelitian ini adalah sebagai berikut :Pasien yang melakukan terapi hemodialisa pada bulan April 2014 - Juni 2014, Pasien dalam keadaan sadar,bersedia menjadi responden dan mampu berbahasa Indonesia.

Jenis data dalam penelitian ini terdiri dari Data primer adalah data yang diperoleh secara langsung dari responden dengan cara pengisian kuesioner. Sedangkan data sekunder yaitu data - data jumlah pasien penderita gagal ginjal kronik yang menjalani hemodialisa yang diperoleh peneliti dari Ruangan Hemodialisa RSUP Haji Adam Malik Medan 2014. Cara pengumpulan data dilakukan dengan menyebarkan kuesioner dimana kuesioner yang digunakan adalah kuesioner tertutup dengan terlebih dahulu memperkenalkan diri, menjelaskan tujuan penelitian, memberikan surat persetujuan menjadi responden, dan memberi kuesioner yang berbentuk multiple choise untuk diisi serta akan dikumpul kembali oleh peneliti untuk diperiksa kelengkapannya. Pengumpulan data dilakukan selama 1 bulan, dari April - Mei 2014. Hari Selasa, tanggal 8 April 2014, peneliti mendapat 12 responden. Hari Rabu, tanggal 9 April 2014, peneliti mendapat 10 responden. Hari Jumat, tanggal 11 April 2014, peneliti mendapat 4 responden. Dan pada hari Senin, tanggal 14 April 2014 mendapat 4 responden. Dengan demikian sampel yang diinginkan peneliti tercapai sebanyak 30 responden.

\section{Pengukuran dan Pengamatan Variabel Penelitian}

Untuk mengetahui tingkat pengetahuan yang dimiliki responden terhadap kepatuhan dalam menjalani terapi hemodialisa yang diajukan 15 pertanyaan menggunakan kriteria yaitu jawaban yang "benar" diberi skor 1 dan jika "salah" diberi skor 0 . Pengetahuan "baik" apabila responden dapat menjawab benar 76-100\% dengan total skor 7-10. Pengetahuan "cukup" apabila responden dapat menjawab benar 56$75 \%$ dengan total skor 4-6. Pengetahuan "kurang" apabila responden dapat menjawab benar $<56 \%$ menjawab benar dengan total skor 0-3

\section{Kepatuhan}

Analisa dilakukan dengan melihat jumlah kehadiran responden dalam menjalani terapi hemodialisa dalam 3 bulan terakhir. Untuk variabel kepatuhan, "patuh" jika jumlah kehadiran 100\% menjalankan terapi hemodialisa dan "tidak patuh" jika jumlah kehadiran < $100 \%$ tidak menjalankan terapi hemodialisa yang telah dianjurkan.

\section{Analisa Data}

Analisa Univariat dilakukan dengan mendeskripsikan besarnya persentase pada masingmasing variabel penelitian dan disajikan dalam bentuk tabel distribusi frekuensi. Sedangkan analisa Bivariat menggunakan uji statistik chi - square $\left(x^{2}\right)$ untuk menganalisis faktor-faktor yang berhubungan dengan kepatuhan pasien penderita gagal ginjal kronik dalam menjalani terapi hemodialis. Ketentuan hubungan dikatakan bermakna bila $\mathrm{p}$ value $<0,05 \mathrm{Ha}$ diterima berarti ada hubungan signifikan antara kedua variable yang diteliti dan hubungan tidak bermakna bila $\mathrm{p}$ value $>0,05$ Ha ditolak.

\section{HASIL PENELITIAN DAN PEMBAHASAN}

\section{Univariat}

Analisa univariat dillakukan untuk melihat distribusi frekuensi dari faktor-faktor yang berhubungan dengan kepatuhan pasien penderita gagal ginjal kronik dalam menjalani terapi hemodialisa.

a. Berdasarkan Distribusi Frekuensi Tingkat Pengetahuan Responden Yang Menjalani Terapi Hemodialisa di Ruang Hemodialisa RSUP Haji Adam Malik Medan Tahun 2014, responden yang memiliki pengetahuan baik sebanyak 14 orang $(46,7 \%)$, pengetahuan cukup sebanyak 12 orang $(40,7 \%)$ dan memiliki pengetahuan kurang sebanyak 4 orang $(13,3 \%)$.

b. Berdasarkan Distribusi Frekuensi Sumber Biaya, responden yang memakai sumber biaya BPJS sebanyak 25 orang $(83,3 \%)$ dan Jamkesmas sebanyak 3 orang $(10 \%)$ dan yang memakai sumber biaya umum sebanyak 2 orang (6,7\%).

c. Distribusi Frekuensi Pendidikan Responden Yang Menjalani Terapi Hemodialisa Di Ruang Hemodialisa RSUP Haji Adam Malik Medan Tahun 2014. Dari 30 responden tingkat pendidikan responden yang berpendidikan SMA sebanyak `15 orang $(46,7 \%)$, Perguruan Tinggi sebanyak 11 orang $(40 \%)$ dan pendidikan SMP sebanyak 4 orang $(13,3 \%)$.

d. Berdasarkan Distribusi Frekuensi Umur Responden Yang Menjalani Terapi Hemodialisa diperoleh hasil bahwa responden berumur $>40$ tahun sebanyak 22 orang $(73,3 \%)$, berumur $25-40$ tahun sebanyak 6 orang $(20 \%)$ dan berumur $<25$ tahun sebanyak 2 orang $(6,7 \%)$. 
e. Distribusi Frekuensi Kepatuhan Responden Yang Menjalani Terapi Di Ruang Hemodialisa RSUP Haji Adam Malik Tahun 2014. Dari 30 responden terdapat responden patuh sebanyak 28 orang $(93,3 \%)$ dan responden tidak patuh sebanyak 2 orang $(6,67 \%)$.

\section{Bivariat}

Analisa bivariat bertujuan untuk mengetahui ada tidaknya hubungan yang bermakna antara faktor-faktor yang berhubungan dengan kepatuhan pasien penderita gagal ginjal kronik dalam menjalani terapi hemodialisa di Ruangan Hemodialisa RSUP Haji Adam Malik Medan Tahun 2014. Pengujian analisa bivariat dilakukan dengan menggunakan Uji Chi square. Analisis ini dikatakan bermakna (signifikan) bila hasil analisis menunjukkan adanya hubungan yang bermakna secara statistik antara variabel, yaitu dengan nilai $\mathrm{p}<$ 0,05 pada tingkat kepercayaan $95 \%$.

a. Hubungan Pengetahuan Dengan Kepatuhan Responden Dalam Menjalani Terapi Hemodialisa di RSUP Haji Adam Malik Medan Tahun 2014.

Dari hasil uji Chi Square terdapat hubungan pengetahuan dengan kepatuhan responden dalam menjalani terapi hemodialisa, diperoleh nilai $p$ value $=0,001(\mathrm{p}<0,05)$ dengan tingkat kepercayaan 95\%. Hal ini menunjukkan adanya hubungan yang bermakna antara pengetahuan dengan kepatuhan pasien penderita gagal ginjal kronik dalam menjalani terapi hemodialisa. Dimana responden dengan pengetahuan yang baik dan cukup lebih patuh dalam menjalani terapi hemodialisa dibandingkan dengan pengetahuan yang kurang.

b. Hubungan Sumber Biaya Dengan Kepatuhan Responden Dalam Menjalani Terapi Hemodialisa di RSUP Haji Adam Malik

Medan Tahun 2014

Hasil uji Chi Square terdapat hubungan sumber biaya dengan kepatuhan responden dalam menjalani terapi hemodialisa diperoleh nilai $p$ value $=$ $0,00(\mathrm{p}<0,05)$ dengan tingkat kepercayaan 95\%. Hali ini menunjukkan adanya hubungan yang bermakna antara sumber biaya dengan kepatuhan pasien dalam menjalani terapi hemodialisa. Dimana responden yang memakai sumber biaya BPJS dan Jamkesmas lebih memengaruhi kepatuhan penderita gagal ginjal kronik dalam menjalani terapi hemodialisa.

c. Hubungan Pendidikan Kepatuhan Responden Dalam Menjalani Terapi Hemodialisa RSUP Haji Adam Malik Medan Tahun 2014. Berdasarkan hasil analisis uji Chi square diketahui terdapat hubungan pendidikan dengan kepatuhan responden dalam menjalani terapi hemodialisa diperoleh nilai $p$ value $=0,001(\mathrm{p}<0,05)$ dengan tingkat kepercayaan $95 \%$. Hal ini menunjukkan adanya hubungan yang bermakna antara pendidikan dengan kepatuhan pasien dalam menjalani terapi hemodialisa. Dimana responden yang memiliki tingkat pendidikan SMA dan Perguruan Tinggi lebih patuh dalam menjalani terapi hemodialisa dibandingkan tingkat pendidikan SMP.

d. Hubungan Umur dengan Kepatuhan Responden Dalam Menjalani Terapi Hemodialisa RSUP Haji Adam Malik Medan Tahun 2014. Berdasarkan hasil analisis uji Chi square diketahui terdapat hubungan umur dengan kepatuhanresponden dalam menjalani terapi hemodialisa dengan nilai $p$ value $=0,014(\mathrm{p}$ $<0,05$ ) dengan tingkat kepercayaan $95 \%$. Hal ini menunjukkan adanya hubungan yang bermakna antara umur dengan kepatuhan pasien dalam menjalani terapi hemodialisa.

e. Hubungan Umur dengan Kepatuhan Responden Dalam Menjalani Terapi Hemodialisa RSUP Haji Adam Malik Medan Tahun 2014. Berdasarkan hasil analisis uji Chi square diketahui terdapat hubungan umur dengan kepatuhanresponden dalam menjalani terapi hemodialisa dengan nilai $p$ value $=0,014(\mathrm{p}$ $<0,05)$ dengan tingkat kepercayaan 95\%. Hal ini menunjukkan adanya hubungan yang bermakna antara umur dengan kepatuhan pasien dalam menjalani terapi hemodialisa.

\section{PEMBAHASAN}

\section{Pengetahuan}

Berdasarkan hasil penelitian yang telah dilakukan kepada 30 orang pasien gagal ginjal kronik yang mengikuti terapi hemodialisa di ruangan hemodialisa RSUP Haji Adam Malik Medan Tahun 2014 diketahui bahwa mayoritas responden yang paling patuh adalah responden yang berpengetahuan baik sebanyak 14 orang $(46,7 \%)$ dan responden yang berpengetahuan cukup sebanyak 12 orang (40,7\%) sedangka responden yang tidak patuh adalah responden yang memiliki pengetahuan kurang sebanyak 2 orang $(6,7 \%)$. Hasil penelitian ini sesuai dengan teori yang ada, Scwhart Griffin dalam buku psikologi kesehatan karangan Neil Nevin (2012) yang mengatakan bahwa tingkat pengetahuan seseorang mempengaruhi kepatuhan seseorang dalam mengikuti program pengobatan. Hal ini disebabkan responden yang memiliki pengetahuan yang baik memiliki banyak sumber informasi mengenai penyakit yang di deritanya sehingga membuat responden dapat mengontrol dirinya dalam mengatasi masalah yang dihadapi, mempunyai rasa percaya diri yang tinggi, berpengalaman, dan mempunyai perkiraan yang tepat bagaimana mengatasi kejadian serta mudah mengerti tentang apa yang dianjurkan oleh petugas kesehatan, akan dapat mengurangi kecemasan sehingga dapat membantu individu tersebut dalam mengambil keputusan dibandingkan responden yang memiliki pengetahuan kurang. Berdasarkan hasil analisis uji Chi Square diperoleh nilai $p$ value $=0,001(\mathrm{p}<0,05)$ dengan tingkat kepercayaan 95\%. Nilai $p$ value ini secara statistik menunjukkan adanya hubungan yang bermakna antara pengetahuan dengan kepatuhan pasien penderita gagal ginjal kronik dalam menjalani terapi hemodialisa. 


\section{Sumber Biaya}

Masalah ekonomi pada terapi hemodialisa merupakan masalah yang sangat mendasar, hal ini berhubungan erat dengan kemiskinan dimana secara umum kemampuan ekonomi suatu keluarga diukur dari pendapatan keluarga perbulan. Dimana dengan ini keluarga dapat memenuhi berbagai pemenuhan kebutuhan hidup dalam pengobatan menjalani terapi hemodialisa. Pendapatan keluarga merupakan sumber terbesar bagi pembiayaan kesehatan. Sehingga tidak heran kalau penghasilan keluarga sangat berpengaruh terhadap kepatuhan dalam melakukan hemodialisa. Maka dari iti disarankan kepada masyarakat menjadi peserta asuransi kesehatan dalam meringankan biaya pengobatan mereka. Berdasarkan hasil penelitian yang telah dilakukan kepada 30 orang pasien gagal ginjal kronik yang mengikuti terapi hemodialisa di ruangan hemodialisa RSUP Haji Adam Malik Medan Tahun 2014 diketahui bahwa responden yang paling patuh berdasarkan sumber biaya adalah responden yang memakai BPJS sebanyak 25 orang $(83,3 \%)$ dan responden yang memakai sumber biaya Jamkesmas sebanyak 3 orang $(10 \%)$ sedangkan responden yang tidak patuh adalah responden dengan sumber biaya yang memakai biaya umum sebanyak 2 orang $(6,7 \%)$. Hasil penelitian ini sesuai dengan teori yang mengatakan bahwa sosial ekonomi merupakan salah satu faktor yang perlu diperhatikan dalam kepatuhan pasien ketika mengikuti terapi yang dianjurkan oleh dokter maupun tenaga medis yang lainnya (Niven, 2012). Menurut peneliti responden yang memakai sumber biaya BPJS lebih terbantu dalam biaya pengobatan. Hal ini disebabkan BPJS membayar fasilitas kesehatan secara efektif dan efisien. BPJS dapat memberikan anggaran tertentu kepada suatu rumah sakit di suatu daerah untuk melayani sejumlah peserta. Berdasarkan hasil analisis uji Chi Square diperoleh nilai $p$ value $=0,00(\mathrm{p}<0,05)$ dengan tingkat kepercayaan $95 \%$. Nilai $p$ value ini secara statistik menunjukkan adanya hubungan yang bermakna antara sumber biaya dengan kepatuhan pasien dalam menjalani terapi hemodialisa.

\section{Pendidikan}

Pendidikan adalah suatu usaha untuk mengembangkan kepribadian dan kemampuan di dalam dan di luar sekolah dan berlangsung seumur hidup. Pendidikan memengaruhi proses belajar, semakin tinggi pendidikan seseorang semakin mudah seseorang makin mudah seseorang tersebut untuk menerima informasi. Dengan pendidikan tinggi maka seseorang akan cenderung untuk mendapatkan informasi, baik dari orang lain maupun media massa. Semakin banyak informasi yang masulk semakin banyak pula pengetahuan yang di dapat tentang kesehatan. Pengetahuan sangat erat kaitannya dengan pendidikan tinggi, maka semakin luas pula pengetahuannya (Notoatmodjo, 2007).

Berdasarkan tabel 4.5 diketahui bahwa responden yang patuh adalah responden dengan tingkat pendidikan SMA sebanyak 15 orang (46,7\%) responden dengan tingkat pendidikan Perguruan Tinggi sebanyak 11 orang $(40 \%)$, sedangkan responden yang tidak patuh dengan tingkat pendidikan SMP sebanyak 2 orang $(6,7 \%)$. Hal ini sesuai dengan teori yang mengatakan bahwa salah satu faktor yang mempengaruhi kepatuhan, adalah dimana semakin tinggi pendidikan seseorang semakin tinggi juga tingkat kepatuhan seseorang. Hal ini disebabkan seseorang yang memiliki tingkat pendidikan yang tinggi akan semakin luas pengetahuan atau sumber informasi yang diperoleh mengenai penyakit yang di deritanya dibandingkan seseorang yang memiliki tingkat pendidikan yang rendah. Berdasarkan hasil analisis uji Chi square diperoleh nilai $p$ value $=0,001(\mathrm{p}<0,05)$ dengan tingkat kepercayaan $95 \%$. Nilai $p$ value ini secara statistik menunjukkan adanya hubungan yang bermakna antara pendidikan dengan kepatuhan pasien dalam menjalani terapi hemodialisa.

\section{Umur}

Dari hasil penelitian yang didapat oleh peneliti, tidak sesuai dengan teori yang mengatakan bahwa kemungkinan semakin tua untuk patuh menjadi lebih kecil dibandingkan dengan umur lebih muda. Melainkan bila ditinjau dari faktor umur, semakin tua umur seseorang, maka perkembangan mentalnya semakin baik, dengan demikian dapat disimpulkan bahwa faktor umur akan mempengaruhi tingkat kepatuhan dalam menjalani terapi hemodialisa (Singgih,D 2001).

Berdasarkan tabel 4.7 didapatkan bahwa responden yang berumur $>40$ tahun sebanyak 22 orang $(73,3 \%)$ dan reponden yang berumur $<25$ tahun sebanyak 2 orang $(6,7 \%)$ sedangkan responden yang tidak patuh adalah responden yang berumur 25-40 tahun sebanyak 2 orang $(13,3 \%)$ dari 6 responden.Menurut peneliti umur merupakan salah satu faktor yang mempengaruhi kepatuhan. Karena semakin bertambah usia akan semakin berkembang pula daya tangkap dan pola pikirnya, sehingga pengetahuan yang diperoleh semakin baik. Hal ini dibuktikan sewaktu pembagian kuesioner, responden yang berumur lebih tua banyak mengetahui tentang terapi hemodialisa. Hemodialisa biasanya menyerang orang yang berusia lanjut. Jadi responden yang berumur tua sudah lama terserang gagal ginjal kronik dan melakukan hemodialisa. Gagal ginjal kronik biasayan menyerang orang yang berusia > 40 tahun. Berdasarkan hasil analisis uji Chi square diperoleh nilai $p$ value $=0,014$ ( $\mathrm{p}<0,05)$ dengan tingkat kepercayaan 95\%. Nilai $p$ value ini secara statistik menunjukkan adanya hubungan yang bermakna antara umur dengan kepatuhan pasien dalam menjalani terapi hemodialisa.

\section{KESIMPULAN}

Dari hasil penelitian "Analisis Faktor-Faktor Yang Berhubungan Dengan Kepatuhan Pasien Penderita Gagal Ginjal Kronik Dalam Menjalani Terapi 
Hemodialisa Di Ruangan Hemodialisa RSUP Haji Adam Malik Medan Tahun 2014" dengan jumlah responden 30 orang, maka dapat disimpulkan bahwa :

1. Adanya hubungan yang bermakna antara pengetahuan dengan kepatuhan pasien penderita gagal ginjal kronik dalam menjalani terapi hemodialisa di Ruang Hemodialisa RSUP Haji Adam Malik Medan Tahun 2014. Dimana responden yang memiliki pengetahuan baik sebanyak 14 orang $(46,7 \%)$, responden yang memiliki pengetahuan yang cukup sebanyak 12 orang $(40,7 \%)$ dan responden yang memiliki pengetahuan yang kurang sebanyak 2 orang $(6,7 \%)$.

2. Adanya hubungan yang bermakna antara sumber biaya dengan kepatuhan pasien penderita gagal ginjal kronik dalam menjalani terapi hemodialisa di Ruang Hemodialisa RSUP Haji Adam Malik Medan Tahun 2014. Dimana responden yang memakai sumber biaya BPJS sebanyak 25 orang $(83,3 \%)$ dan responden yang memakai sumber biaya Jamkesmas sebanyak 3 orang $(10 \%)$ dan sumber biaya umum sebanyak 2 orang $(6,7 \%)$ tidak patuh karena tidak punya uang.

3. Adanya hubungan yang bermakna antara pendidikan dengan kepatuhan pasien penderita gagal ginjal kronik dalam menjalani terapi hemodialisa di Ruang Hemodialisa RSUP Haji Adam Malik Medan Tahun 2014. Dimana responden yang pendidikan SMA sebanyak 15 orang $(46,7 \%)$ dari 30 responden lebih patuh dibandingkan responden denganresponden dengan tingkat pendidikan Perguruan Tinggi sebanyak 11 orang $(40 \%)$, responden dengan tingkat pendidikan SMP sebanyak 2 orang $(6,7 \%)$, dan responden yang tidak patuh adalah responden yang memiliki tingkat pendidikan SMP sebanyak 2 orang $(6,7 \%)$.

4. Adanya hubungan yang bermakna antara umur dengan kepatuhan pasien penderita gagal ginjal kronik dalam menjalani terapi hemodialisa di Ruang Hemodialisa RSUP Haji Adam Malik Medan Tahun 2014. Dimana responden yang berumur $>40$ tahun sebanyak 22 orang $(73,3 \%)$ responden yang berumur $<25$ tahun sebanyak 2 orang $(6,7 \%)$ responden yang berumur 25-40 tahun sebanyak 4 orang $(13,3 \%)$ dan yang tidak patuh aalah responden yang berumur 25 40 tahun sebanyak 2 orang $(6,7 \%)$ dari 30 responden.

\section{SARAN}

1. Kepada seluruh keluarga pasien gagal ginjal kronik yang mengalami tindakan hemodialisa agar menjadi peserta asuransi kesehatan seperti BPJS dan Jamkesmas, agar pasien penderita gagal ginjal kronik lebih ringan dalam biaya pengobatan dan patuh dalam menjalani terapi hemiodialisa.
2. Untuk pihak rumah sakit supaya lebih meningkatkan upaya untuk melakukan pelatihan atau seminar tentang tindakan hemodialisa dalam upaya meningkatkan kesehatan pasien.

3. Kepada pasien gagal ginjal kronik agar meningkatkan kepatuhan dalam melakukan tindakan hemodialisa sesuai dengan jadwal yang ditentukan dalam upaya peningkatan kesehatan.

\section{DAFTAR PUSTAKA}

Alimul, A, 2007. Riset Keperawatan dan Teknik Penulisan Ilmiah. Jakarta: Salemba

Arikunto, S, 2006. Prosedur Penelitian Suatu Pendekatan Praktek. Jakarta : Rineka Cipta

Brunner dan Suddart, 2008. Keperawatan Medikal Bedah. Jakarta: EGC

Cahyaningsih, N. 2011. Hemodialisis. Yogyakarta: Mitra Cendikia Press

Chang, 2009. Patofisiologi. Jakarta: EGC

Callaghan. 2007. Sistem Ginjal. Jakarta: EMS

Haryono, 2013. Sistem Perkemihan. Yogyakarta: ANDI

Lumenta, N. 2008. Penyakit Ginjal. Jakarta: Gunung Mulia

Mahdiana, R. 2011. Panduan Jantung dan Ginjal. Yogyakarta: Citra Medikal

Niven, N. 2002. Psikologi Kesehatan. Jakarta: EGC

Notoatmodjo, S. 2010. Metode Penelitian Kesehatan. Jakarta: Rineka Cipta

Pernefri, 2011.Perilaku pasien penderita gagal ginjal kronik dalam menjalani hemodialisa, Indonesia, http:// prilaku-pasien-penderitagagal-ginjal.html. Diunduh pada tanggal 14 Januari 2014

Robbins, 2007. Buku Ajar Patologi. Jakarta: EGC

Rully, 2011 pasien gagal ginjal kronik di Indonesia. Jumlah. http://www.jumlah -pasien-gagalginjal-kronik di Indonesia, Diunduh pada tanggal 9 januari 2014

Suharyanto, 2009. Asuhan Keperawatan Pada Klien dengan Gangguan Sistem Perkemihan, TIM, Jakarta

Thata, M,dkk, 2009. Abstrak Penelitian Penyakit Ginjal Kronik, http://library.itd.unair.ac.id/files/disk1/4/itdunair -mochammadt-160-1-abstrak-2-pdf, diunduh tanggal 15 januari 2014. 